\title{
MEDICINE
}

\section{FEATURES OF THE COMORBID FLOW OF UNSTABLE STENOCARDIA AND THE ANXIETY-DEPRESSIVE SYNDROME DEPENDING ON THE BLOOD CYTOKINE LEVEL}

\author{
${ }^{1}$ Doctoral student Nasyrova Zarina Akbarovna \\ ${ }^{2}$ Doctor of Medical Sciences Tashkenbaeva Eleonora Negmatovna \\ ${ }^{1}$ Uzbekistan, Samarkand, Samarkand State Medical Institute \\ Samarkand Branch of the Republican Scientific Center for Emergency Medical Aid \\ ${ }^{2}$ Uzbekistan, Samarkand, Samarkand State Medical Institute \\ Samarkand Branch of the Republican Scientific Center for Emergency Medical Aid
}

DOI: https://doi.org/10.31435/rsglobal_sr/30062019/6542

\section{ARTICLE INFO}

Received 16 April 2019

Accepted 25 June 2019

Published 30 June 2019

\section{KEYWORDS}

affective disorders, unstable angina, pro-inflammatory cytokines, anti-inflammatory cytokines.

ABSTRACT

195 patients (102 men and 93 women) aged from 35 to 75 years (mean age $62.57 \pm 0.75$ years) suffering from unstable forms of IHD were examined on the basis of the SB RSCEMA in the emergency and cardiac resuscitation departments. All patients were tested using the Hospital Anxiety and Depression Scale. Based on the psychopathological examination data, all patients were divided into 2 groups. The first group included 109 patients with unstable angina with clinically significant affective disorders, which amounted to $55.89 \%$. The second - the comparison group - $86(44.1 \%)$ patients with unstable angina without affective disorders. Studies have shown that when comparing inflammatory markers - cytokines in patients with unstable angina, the pro-inflammatory cytokines IL-1 and TNF $\alpha$ are increased in individuals with comorbid pathology, depending on the presence or absence of affective disorders of the anxiety-depressive spectrum.
\end{abstract}

Citation: Nasyrova Z. A., Tashkenbaeva E. N. (2019) Features of the Comorbid Flow of Unstable Stenocardia and the Anxiety-Depressive Syndrome Depending on the Blood Cytokine Level. Science Review. 5(22). doi: 10.31435/rsglobal_sr/30062019/6542

Copyright: (C) 2019 Nasyrova Z. A., Tashkenbaeva E. N. This is an open-access article distributed under the terms of the Creative Commons Attribution License (CC BY). The use, distribution or reproduction in other forums is permitted, provided the original author(s) or licensor are credited and that the original publication in this journal is cited, in accordance with accepted academic practice. No use, distribution or reproduction is permitted which does not comply with these terms.

Introduction. Coronary diseases are the leading cause of death and disability in all developed countries of the world [1, 2]. The contribution of coronary heart disease (CHD) in mortality from cardiovascular events (CVS) is about 50\%. Considering the great clinical and social significance of IHD, the identification and study of new factors predisposing to the deterioration of its course, as well as the development of measures aimed at preserving the health of citizens, are urgent tasks of modern healthcare [3, 4]. Today, one of the main risk factors is affective disorders in patients with coronary artery disease. Correction of affective disorders is one of the main promising approaches for effective treatment and reducing mortality in patients with coronary artery disease. The basic molecular-cellular mechanisms underlying the development of affect disorders are the functioning of the hypothalamicpituitary-adrenal neuroendocrine axis, and in the brain the balance of neurotransmitters and neurotrophic factors, as well as the cytokine system. Disruption of these interconnected systems, leading to many structural and functional abnormalities in the brain, underlies the pathogenesis of affective disorders, and this condition contributes to the deterioration of the prognosis of IHD. 
However, there are practically no studies on the content of cytokines in the peripheral blood of IHD patients suffering from affective disorders $[6,7]$.

Objective: to study the effect of affective disorders on the level of cytokines in unstable angina.

Research materials. 195 patients (102 men and 93 women) aged from 35 to 75 years (average age $62.57 \pm 0.75$ years) were examined on the basis of the Samarkand branch of the Republican Scientific Center for Emergency Medical Aid in the departments of emergency therapy and cardiac rescuscitation, suffering from unstable forms of CHD. All patients were tested using the Hospital Anxiety and Depression Scale. All patients were tested using the Hospital Anxiety and Depression Scale. Blood sampling was done on an empty stomach, between 7 and 8 in the morning. The cytokine content was determined by the method of multiplex analysis of proteins on a BioPlex device (BioRad, USA), using appropriate commercial test systems for determining IL-1 $\beta$, IL-4, IL-10 and also TNF $\alpha$ (BioRad, USA). Statistical processing of the results was carried out using the statistical package SPSS 14.0. Data are presented as mean values with a mean square error of the mean. The significance of differences was assessed using the Mann - Whitney test. Affective disorders were assessed using the Spielberg-Hanin scale and the Hospital Anxiety and Depression Scale (HADS).

Results. Based on the data of psychopathological examination, all patients were divided into 2 groups. The first group included 109 patients with unstable angina with clinically significant affective disorders, which amounted to $55.89 \%$. The second - the comparison group - 86 (44.1\%) patients with unstable angina without affective disorders. In turn, patients from the main surveyed group were divided into three subgroups depending on the type of affective disorder: isolated depressive in 27 $(24.77 \%)$ patients, isolated anxiety disorder in $53(48.62 \%)$ patients and a comorbid variant of similar disorders mood - anxious depression in 29 (26.6\%) patients. When comparing the main surveyed group with the comparison group on the main demographic and clinical characteristics, it was found that among patients with unstable angina, combined with anxiously depressive disorders, there were more women than among patients with unstable angina without affective disorders. This accounted for $65.6 \%$ of the total number of women. The analysis of the content of proinflammatory cytokines in the serum showed that in patients with unstable angina in combination with affective disorders, levels of proinflammatory cytokines, such as IL- 1 and TNF $\alpha$, were higher than in patients with unstable angina without mood disturbances and these differences were statistically significant $(\mathrm{p}<0.05)$. The levels of pro-inflammatory cytokines were also analyzed in groups of patients with unstable angina, suffering from isolated depressive, isolated anxiety disorders and anxious depression, in comparison with the control group. In the group of patients with unstable angina, combined with anxiety, the level of IL-1 was significantly higher. In the group of patients with unstable angina in combination with depression, the levels of IL-1 and TNF $\alpha$ were significantly higher. In the group of patients with unstable angina in combination with anxious depression, the level of $\mathrm{TNF} \alpha$ was significantly higher. Indicators of antiinflammatory cytokines, such as IL-4 and IL-10, on the contrary, were significantly reduced in patients with unstable angina with affective disorders, indicating an unfavorable prognosis of this disease and the need for timely correction.

Conclusions. Thus, patients with NS with anxiety-depressive syndrome hospitalized in emergency medical care are recommended to be screened on the HADS and Spielberger-Khanin scales for all patients with coronary heart disease to identify anxiety-depressive syndrome, since the comorbidity of these pathologies worsens the course of the disease, and a prognosis for cardiovascular events that contributes to a decrease in survival.

When comparing inflammatory markers - cytokines in patients with unstable angina, depending on the presence or absence of affective disorders of the anxiety-depressive spectrum, results were obtained associated with an increase in IL-1 and TNF $\alpha$ in patients with comorbid pathology, which indicates the need to include antidepressant drugs.

\section{REFERENCES}

1. Kadyrova F. et al. Поширеність бессимптомно гіперурикеміi серед хворих з ішемічною хворобою// Здобутки клінічної і експериментальної медицини. - 2017. - №. 2.

2. Бисалиев Р.В., Кубекова А.С., Хаджимурадов А.В. Агрессивное поведение в структуре соматических расстройств // Современные проблемы науки и образования. -2013 . - № 5 .

3. Кадырова Ф. и др. Распространенность бессимптомной гиперурикемии среди больных ишемической болезнью сердца //Здобутки клінічної і експериментальної медицини. - 2017. - С. 53. 
4. Козлова С.Н. Коморбидность ишемической болезни сердца и аффективных расстройств тревожнодепрессивного спектра: клинико-патогенетические аспекты, прогноз и возможности медикаментозной коррекции// Диссертация. - 2013 год. Санкт-Петербург. С. 19.

5. Насырова 3. А., Абдуллаев К. 3. ВЛИЯНИЕ ЦИТОКИНОВ НА ТЕЧЕНИЕ НЕСТАБИЛЬНОЙ СТЕНОКАРДИИ// Научный журнал №3(37), 2019, С47-52

6. Насырова 3.А., Шарапова Ю.Ш., Хасанжанова Ф.О. ВЛИЯНИЕ АФФЕКТИВНЫХ РАССТРОЙСТВ НА ПРОГРЕССИРОВАНИЕ ИШЕМИЧЕСКОЙ БОЛЕЗНИ СЕРДЦА// НаучнЫЙ журнал №3(37), 2019, С. $42-47$

7. Ташкенбаева Э. Н., Хасанжанова Ф. О., АбдулЛаев К. З. ОСОБЕННОСТИ ТЕЧЕНИЯ НЕСТАБИЛЬНОЙ СТЕНОКАРДИИ У БОЛЬНЫХ ХРОНИЧЕСКОЙ СЕРДЕЧНОЙ НЕДОСТАТОЧНОСТЬЮ СО СНИЖЕННОЙ ФРАКЦИЕЙ ВЫБРОСА //Наука и современное общество: взаимодействие и развитие. 2018. - T. 2. - №. 1. - C. 34-36. 